\title{
„Ziemia otworzy usta”" O wyobraźni forensycznej Erny Rosenstein
}

\author{
Droga, na której nikogo. \\ Ślad wymiatają obłoki. \\ Werbel poległym biją kroki. \\ Olbrzymieją sekundy. \\ Jutro zanieistniałe. \\ Wszystkie słowa są białe, \\ a każde znaczy wszystko. \\ E. Rosenstein: Kierunek (C, s. 40)
}

\section{Forensyczna sprawiedliwość}

W poezji Erny Rosenstein, żydowskiej artystki, wieloletniej członkini Grupy Krakowskiej, której rodzice zostali zamordowani przez szantażystę po ucieczce

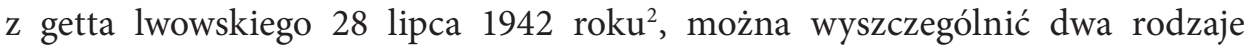
obrazowania. Pierwszy koncentruje się wokół stanów komplementarnych wobec izolacji, ukrycia - są to: zamknięcie (Narasta, WS, s. 70), odosobnienie (Komora,

${ }^{1}$ E. Rosenstein: Dokąd. W: Taż: Czas. Warszawa 1986, s. 30. Dalej stosuję skrót C i numer strony. Pozostałe tomy oznaczam kolejno skrótami: Ś (Ślad. Warszawa 1972), SGM (Spoza granic mowy. Warszawa 1976), WS (Wszystkie ścieżki (wiersze wybrane). Kraków 1979), TA (Trochę z archiwum. Legionowo 1993).

2 Artystka opowiedziała o swoich okupacyjnych doświadczeniach Łukaszowi Guzkowi i Zenonie Macużance w dwóch wywiadach. Zob. Erna Rosenstein. Red. i układ graf. J. Снвовак. Kraków 1992, s. 3-37, 44-63. 
WS, s. 74), zniszczenie (Tak jestem, WS, s. 76), w końcu zniknięcie (Zniknięcie, WS, s. 11), jak w wierszu Ogromne:

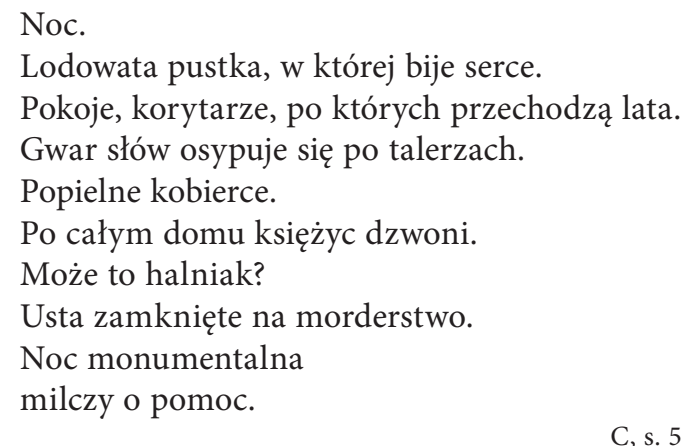

W utworze tym niepokój wywołuje antynomiczne zestawienie słów konotujących bezpieczeństwo (dom, pokój) i zagrożenie (pustka, korytarze), które wzmagają efekt klaustrofobii i zamurowania. Rosenstein podważa sens wyjawienia źródła traumy („usta zamknięte na morderstwo”) ze względu na nieobecność domowników mogących jej wysłuchać (świadczy o tym fraza zwracająca uwagę na materialność gwaru słów „osypującego się” po talerzach). Świat po Zagładzie wyludnił się (warto zapamiętać tę konstatację, ponieważ w latach 90. poetka całkowicie zrezygnuje z ludzkich podmiotów i skieruje uwagę ku nie-ludzkim aktantom), a fakt dokonania morderstwa został przemilczany; nie można go przekazać w satysfakcjonującej formie tym, którzy mogliby stać się depozytariuszami prawdy o ocaleniu.

W poezji Rosenstein dochodzi do rozmontowania dychotomicznego ujęcia roli świadka superstes/testis zaproponowanego przez Giorgia Agambena. Pierwsza kategoria zarezerwowana jest w pismach włoskiego filozofa dla tych, którzy coś przetrwali i mogą dać temu świadectwo, druga zaś dotyczy osób występujących w charakterze osoby trzeciej w postępowaniu sądowym ${ }^{3}$. Superstes składa relację o wydarzeniu granicznym, a testis - świadek sądowy - w sposób chłodny i zdystansowany opowiada o zaobserwowanych wydarzeniach, ważąc słowa, dbając o dyscyplinowanie autorskiego „ja”. Rosenstein, akcentując własną niemotę („Nie umiem otworzyć ust. / Mówią moje ramiona” - C, s. 13), składa fragmentaryczne świadectwo, które wiąże się z prywatną biografią, jednak w perspektywie globalnej stanowi exemplum losów zbiegów z gett Europy Wschodniej. Obrazy zamknięcia, odosobnienia, pustki wiążą się z przeżyciem intymnej katastrofy, która legła u podstaw jej światopoglądu oraz naznaczyła twórczość niezabliźnioną raną. Jednak na przeciwległym biegunie pojawia się

${ }^{3}$ Por. G. Agamben: Co zostaje z Auschwitz. Archiwum i świadek. Przeł. S. KRólak. Warszawa 2008 , s. 15. 
pragnienie wypowiedzenia (bez konieczności zdawania szczegółowego raportu), którego hiperboliczny obraz zawiera wiersz Samotna ${ }^{4}$ :

Tak strasznie samotna, że jest jak gdyby jej język wyrwali i tym wyrwanym językiem mówi teraz do nikogo.

$$
\text { WS, s. } 28
$$

Dojmujące poczucie samotności, na które zwrócił uwagę Paweł Dybel, pisząc o natrętnie powracającym motywie zamkniętego domu ${ }^{5}$, rozciąga się także na niematerialną sferę życia (bezdomność jest tu kondycją psychiczną): „Życie bowiem - tak naprawdę - nie dało żadnego punktu zaczepienia, miejsca, w którym można by się zadomowić i z nim utożsamić"'.

Obrazy drugiego rodzaju natomiast, $\mathrm{w}$ przeciwieństwie do poprzedniego, który konsekwentnie prezentował wyobraźnię wsobną, eksplodują, przekraczają granice, podkreślają metamorfozy, jak w Cmentarzu:

Jak okrągleje ta ziemia.

Jak obrasta sutkami.

Ile kul wyrzuciła na wierzch.

Z samej głębi wynosi

i jeszcze...

Tyle piersi wyrzuca...

Tyle w nich serc uderza...

Tak niemo...

Dudnią pod spodem całe góry ciszy.

Ziemia się w ziemi rozszerza.

Szpary mnożą się w szpary.

Cień osypuje się sobą.

$[\ldots]$

SGM, s. 41

Nietrudno wskazać malarskie inspiracje Rosenstein. Pierwszy wiersz niewątpliwie wiele zawdzięcza Eine Kleine Nachtmusik (1946) Dorothei Tanning, drugi natomiast ilustruje przeszczepienie malarskiego języka René Magritte’a, który

${ }^{4}$ Sugestywny opis stanu po Zagładzie zawiera wiersz Podróż: „A ja tu właśnie mijam. / Rozdzieram obrazy. Idę przez nie i zlepiam. / Przeszłość mruga do mnie oczyma jak matka. / Nieodwołalna mijaniem. / Miganiem mijania. // Przechodzę obok siebie. / Obok swego życia. / Niema. / I zupełnie sama / do ostatka" (C, s. 28-29).

${ }^{5}$ Wersją zaanektowaną przez surrealistów, przeszczepioną z romantyzmu, jest zamek, którego prototyp stworzył Horace Walpole w Zamczysku w Otranto. Zob. M. BARANowsKa: Surrealna wyobraźnia i poezja. Warszawa 1984, s. 64 i nast.

6 P. Dyвel: Pęknięty czas. „Twórczość” 1980, nr 6, s. 123. 
charakteryzuje „efekt wyobcowania (franc. dépaysement) przedmiotów z właściwego im kontekstu, co powoduje pozbawienie ich przypisywanego im znaczenia i nadaje im nowy, zazwyczaj zagadkowy sens"'. Obraz ziemi obrastającej sutkami i wyrzuconymi na wierzch pulsującymi sercami można skonfrontować z Groźna pogoda (1928), Dola człowiecza (1934), Filozofia w buduarze (1947) lub Zamkiem w Pirenejach (1959) Magritte'a.

Wszystkie one opierają się na zestawieniu realistycznej sceny $\mathrm{z}$ detalem, który wzbudza niepokój ${ }^{8}$. Stanowią także rodzaj komentarza w sprawach różnej rangi: albo dotyczących przeznaczenia sztuki (odwieczne pytanie: powielać czy kreować?), albo relacji miłosnej opartej na męskim szowinizmie i wzrokocentryzmie. Przeznaczeniem niektórych z nich jest - jak podkreśla Krystyna Janicka ewokować tajemnicę i wzbudzać w oglądającym dreszcz grozy lub zachwyt, co znamionuje akt artystycznej percepcji sztuki surrealnej'.

Zestawienie tych dwóch wierszy, poza uświadomieniem stopnia powiązań między światopoglądem surrealistó $w^{10}$ a Rosenstein, świadczy o silnie oddziałującej wyobraźni forensycznej. Jej wyznacznikami są nie tylko mizerabilizm (Ptak, C, s. 68), pojawiające się destrukty wiążące to, co ludzkie, i to, co nie-ludzkie, w formie asamblaży, lecz również obszary chtoniczne (Cmentarz, WS, s. 137), zawierające tajemnicę oraz wskazujące początek i koniec ludzkiej egzystencji ( $W$ zieleni, C, s. 97), a także materialne ślady zmarłych, mające kluczowe znaczenie $\mathrm{w}$ procesie upamiętnienia nazistowskich ofiar. Wyobraźnia forensyczna jest rodzajem zobowiązania wobec zamordowanych i niegodnych żałoby, ale też żywych, mających szansę, jak pisze Roma Sendyka, zamanifestować (zgodnie ze znaczeniem słowa forensis - z łaciny 'odnoszenie się do forum') gotowość do upublicznienia sprzeciwu wobec podważania prawa ludzi i nie-ludzi do przeżycia. (Postulat ten realizują wiersze zgromadzone w dziale Pomnik tym, którzy nie mówia z tomu Wszystkie ścieżki z 1979 roku) ${ }^{11}$. W tak zakrojonym

${ }^{7}$ K. JANICKA: Surrealizm. Warszawa 1985, s. 99.

${ }^{8}$ Cmentarz został przedrukowany w tomie wierszy zebranych, $\mathrm{w}$ dziale o znamiennym tytule Obecność..., obok tekstów, które jednoznacznie wskazują, że w wyniku Zagłady odwróceniu uległa dotychczasowa waloryzacja tego, co stałe, i tego, co ulotne, stąd puenta Nieruchomych: „Niedomówienia wasze / cała ta błahość - granit” (WS, s. 126).

${ }^{9}$ Por. K. Janicka: Surrealizm..., s. 107.

${ }^{10}$ Jakub Kornhauser, śledząc awangardowe inspiracje w powojennej poezji polskiej, pisał: „Surrealizmu nigdy w Polsce nie było. I to jest tym ciekawsze, że surrealizmów było doprawdy bez liku. Być może - wbrew pierwotnym intencjom swych promotorów - surrealizmy rozpierzchły się w rozmaitych kierunkach, przyjmując różnorodne formy i miana, kojarząc się z napotkanymi na swej drodze tworami, stale ewoluując i poszerzając zakres swoich zainteresowań" (TEnżE: Awangarda. Strajki, zakłócenia, deformacje. Kraków 2017, s. 66). Badacz za kontynuatorów poetyki surrealnej skłonny jest, mimo cytowanej opinii, uznać Jerzego Harasymowicza, Zbigniewa Herberta, Andrzeja Sosnowskiego i Adama Wiedemanna.

${ }^{11}$ Por. R. Sendyka: W imię zmarlych: humanistyka forensycznej wrażliwości i publicznej prawdomówności. „Teksty Drugie” 2017, nr 1, s. 89. 
projekcie sztuka Rosenstein objawia możliwość ukonstytuowania nowych form międzygatunkowej kohabitacji i stawia sobie za cel czynienie życia znośniejszym oraz bezpieczniejszym dla coraz większej liczby ludzi, ponieważ „Na całej kuli ziemskiej bije ciszą w naszych żyłach / puls tej samej krwi. / Ten sam rytm co w trawie" (WS, s. 106-107).

Drugie znaczenie słowa „forensyczny” wiąże się z rozwijającym się zwrotem sądowym/śledczym, który, jak podkreśla Ewa Domańska, dowartościowuje dowody rzeczowe, mające decydujące znaczenie w momencie dyskusji na temat sprawstwa i możliwości dochodzenia prawdy na podstawie nie-ludzkich i wiarygodnych aktantów, a nawet ekofaktów ${ }^{12}$. Forensyczność, jako praktyka związana z procedurami zapewniającymi ujawnienie prawdy i wszczęcie wieloetapowego dochodzenia $\mathrm{w}$ celu wykrycia mordercy, pojawia się także w poezji Rosenstein, której naczelnym tematem, powracającym w wierszach, malarstwie oraz asamblażach wykonywanych od lat 60., jest Zagłada, a dokładniej jeden epizod - wspomniane zabójstwo rodziców z rąk szantażysty w lesie nieopodal Małkini. Poetka zdołała ocaleć, jednak w jej kolejnych tomach oraz sztuce pojawiają się elementy składające się na nekroperformans, wiążące to, co materialne, cielesne, oraz praktyki archiwalne ${ }^{13}$ (między innymi gromadzenie i zabezpieczanie).

W kolejnych tomach Rosenstein coraz wyraźniej można dostrzec wpływ praktyk śledczych na wyobraźnię artystki, która anektując forensyczny słownik (ślad, morderstwo, krajobraz cynegetyczny, narzędzie zbrodni), upomina się o zmarłych oraz dopuszcza w obrębie narracji o Zagładzie wątki sensacyjne zgodnie z założeniem Rity Felski dotyczącym szoku jako jednego z kluczowych sposobów odbioru sztuki ${ }^{14}$. Podstawowym chwytem wywołującym go jest afekt: „[...] możemy być bardziej wstrząśnięci i wytrąceni z równowagi przez skręcające wnętrzności sztuki Sarah Kane niż przez dowolną liczbę zgonów, o których przeczytaliśmy w gazecie"15. Teza o sensacyjności, którą formułuje sztuka Rosenstein, mogłaby okazać się fałszywa, gdyby nie fakt, że tropem tym podążają również Dorota Jarecka i Barbara Piwowarska - autorki monograficznego opracowania jej twórczości - przyjmując, że obraz Ekrany, jeden z najsłynniejszych i pierwszych portretów rodziców z odciętymi głowami (namalowany w 1951 roku), mógł być oglądany na tzw. Wystawie Dziewięciu w 1955 roku w Krakowie lub na indywidualnej wystawie artystki w Zachęcie w 1967 roku przez zabójcę ${ }^{16}$.

12 Zob. E. Domańska: Nekros. Wprowadzenie do ontologii martwego ciała. Warszawa 2017, s. 138-139.

${ }^{13}$ Zob. D. Sajewska: Nekroperformans. Kulturowa rekonstrukcja teatru Wielkiej Wojny. Warszawa 2016.

${ }^{14}$ Por. R. Felski: Literatura $w$ użciu. Przeł. J. Borkowska, K. Dembowy, K. Ignaczak i in. Poznań 2016, s. 64.

15 Tamże, s. 126.

${ }^{16}$ Por. D. Jarecka, B. Piwowarska: Erna Rosenstein. Mogę powtarzać tylko nieświadomie / I Can Repeat Only Unconsciously. Warszawa 2014, s. 118. 
Sensacyjne są także portrety rodziców: Pótnoc (Portret matki) i Świt (Portret ojca) z 1979 roku $^{17}$, ponieważ artystka porzuca zasadę decorum na rzecz dosłowności i naturalizmu, co pozwala „śmierć rodziców wydobyć z masowego tła, nadać jej charakter indywidualny, dopełnić rytuału, którego Zagłada oraz jej obrzeża ofiarom odmawiały"18. Podstawą reprodukowanych wizerunków zdekapitowanych rodziców były przedwojenne zdjęcia, których negatywy zdołał zakopać właściciel zakładu fotograficznego ${ }^{19}$. Proces odtwarzania twarzy rodziców wiąże się więc również ze zstąpieniem pod ziemię i z wydobyciem skarbu. Portrety oddziałują z niespotykaną mocą dzięki zachowaniu indywidualnych rysów, podkreśleniu faktu morderstwa przez każdorazowe pozbawienie rodziców głów oraz zaakcentowaniu różnych momentów ich śmierci (tę „narracyjność" wprowadzają detale: na szyi matki krew wydaje się jeszcze niezakrzepła, natomiast twarz ojca przybiera odcień trupiej niebieskości, oczy stały się już zamglone). Zabiegi te umożliwiają uaktywnienie „wyobraźni relacyjnej”, której działanie wyjaśnia Dorota Głowacka:

Ponieważ podmiotowość jest ustanawiana przez związki z innym, moja własna istota rozpada się, a moje człowieczeństwo zostaje podane w wątpliwość, gdy innego dotyka przemoc, cierpienie, upokorzenie i śmierć [...]. Wyobraźnia relacyjna, czy też „wyobraźnia-z-innymi”, poprzedza więc pojęcie wyobraźni rozumianej jako najwyższy wyraz osobistej wolności. Jest ona niezbędna, abyśmy byli w stanie uzmysłowić sobie, czym jest cierpienie drugiego człowieka, oraz przyjąć, że jego prawo do bycia wolnym od cierpienia spoczywa również na naszych barkach ${ }^{20}$.

Założenia badaczki okazują się komplementarne wobec poczynań Rosenstein, która (nawet jeśli nie widziała momentu zabójstwa) kształtuje własną, oddziałującą afektywnie na oglądającego, historię morderstwa dwojga starszych ludzi. Co ważne: w wywiadach, wspomnieniach i nagraniu dźwiękowym artystka rekonstruuje linearną narrację, która respektuje zasady klasycznej opowieści (posługując się, jak podkreśla Jarecka ${ }^{21}$, językiem dokumentu), natomiast poezja, malarstwo i asamblaże umożliwiają nowe, oryginalne opracowanie tematu, które angażuje czytelnika/obserwatora, opierając się na zasadach współbycia i współodczuwania z córką zamordowanych. Jarecka dodaje, że na obrazach pojawia się

${ }_{17}$ Z 1973 r. pochodzą dwa obrazy Anny i Maksymiliana Rosensteinów: Portret I (Portret matki) oraz Portret II (Portret ojca), które oddziałują na widza z powodu duplikacji portretów i rozmieszczenia ich na całej powierzchni płótna, co daje efekt napierania, nadmiaru oraz natarczywości hauntologicznej wizji zmarłych upominających się o pamięć.

${ }_{18}$ D. Jarecka, B. Piwowarska: Erna Rosenstein..., s. 118.

19 Por. tamże, s. 79.

20 D. GŁowacka: Po tamtej stronie. Świadectwo - afekt - wyobraźnia. Warszawa 2016, s. 191192.

${ }^{21}$ Por. D. Jarecka, B. Piwowarska: Erna Rosenstein..., s. 96. 
to, co szalone, żenujące, wstydliwe ${ }^{22}$ i co nie mogłoby zostać wyartykułowane w innej formie. Uprzywilejowanymi obszarami eksperymentu okazują się poezja i sztuka, które dzięki forensycznej wrażliwości Rosenstein pozwalają artystce zająć miejsce tłumacza, twórcy prozopopei ${ }^{23}$ :

Jestem ojciec i matka.

Rozsypuję ich słowa.

Właściwie,

kiedy rozwieram wargi,

mówią oni sami.

$[\ldots]$

Jaki głos moim głosem cokolwiek powtarza?

SGM, s. 5

Strategia wierności umarłym oraz akcentowania etyki i odpowiedzialności ${ }^{24}$, o których pisze Domańska, bliska jest także prezentowanym tu praktykom Rosenstein. Patronką jej działań można uczynić Judith Butler. Filozofka wydobywa „na światło dzienne nie tylko skończony charakter życia”, ale i kruchość (vulnerability) tego istnienia, które jeszcze trwa ${ }^{25}$. Dodaje, że: „Uznanie, iż kruchość jest wspólna nam wszystkim, wprowadza silne normatywne zaangażowanie na rzecz równości” ${ }^{26}$. Jedną z jej form jest domaganie się - mimo codziennych raportów o ofiarach śmiertelnych, które znieczulają opinię publiczną - uznania szczególnej wartości pojedynczego ludzkiego życia (nawet gdy przynależy ono do wrogiej nacji).

Tak sprecyzowany zakres działań forensycznych można odnieść do sytuacji Żydów zamkniętych w gettach okupowanej Europy; rzadko (jeśli w ogóle) pojawia się konstatacja, że śmierć większości z nich na skutek deportacji, masakr lub pojedynczych egzekucji powinna otrzymać kwalifikację morderstwa (często ze szczególnym okrucieństwem ${ }^{27}$ ). Z uwagi na brak możliwości podjęcia czynności mających ustalić stopień zaniedbań i ich wpływ na zgon denatów wspominający czas Zagłady ograniczają się do podania przyczyn śmierci:

${ }^{22}$ Zob. tamże.

${ }^{23}$ Por. R. Sendyka: $W$ imie zmartych..., s. 88.

24 Zob. E. Domańska: Nekros..., s. 147.

25 J. Butler: Ramy wojny. Kiedy życie godne jest opłakiwania? Przeł. A. Czarnacka. Warszawa 2011, s. 57.

26 Tamże, s. 76.

27 Jeden z drastyczniejszych przykładów podaje Marek Edelman: „Nawet posłali tam chłopca, który nie doszedł (spalili go na Miłej, przez cały dzień słychać było jego krzyk), a chwila, w której Anielewicz dostał wiadomość, to była ta jedyna chwila, gdy odzyskał nadzieję, choć przecież od razu mówili mu, że nic z tego nie może wyjść, że się tam nikt nie przedostanie" (H. Krall: Zdązyć przed Panem Bogiem. Hipnoza. Biała Maria. Warszawa 2013, s. 87). 
Tutaj chowano wszystkich, którzy zmarli jeszcze przed likwidacją getta - z głodu, na tyfus, z wycieńczenia na ulicy, w opuszczonych mieszkaniach. Co rano pracownicy Towarzystwa „Wieczność” wychodzili z ręcznymi wózkami, zbierali z ulic ciała i układali stosami na wózkach, jedne na drugich, następnie przecinali jezdnię na Okopowej, wyjeżdżali na cmentarz, który był po aryjskiej stronie, i szli tędy, aleją, do muru ${ }^{28}$.

Marek Edelman mówi też o przypadku Seweryna Majdego, który cisnął w głowę jednego z żandarmów ciężką popielnicą ${ }^{29}$, za co został rozstrzelany. Ze względu na to, że był to jedyny znany wypadek celowej samoobrony, jego personalia oraz sposób śmierci zostały utrwalone i przekazane Hannie Krall. Zasadą organizującą selekcję informacji dotyczących zgonów był więc eksces, wyłom w rutynowym poddawaniu się woli okupanta, a także przydatność w szeregach organizacji, stąd rekonstrukcja losów łączniczki ŻOB-u, która kolportowała gazetki do Piotrkowa: „Kiedyś w drodze powrotnej złapali ją Ukraińcy i chcieli zastrzelić, ale nasi ludzie zdołali wetknąć im jakieś pieniądze; Ukraińcy postawili ją nad grobem, strzelili ślepymi nabojami, ona udała, że pada, a potem nadal woziła do Piotrkowa te gazetki" ${ }^{30}$.

Jeśli w zapisach diarystów pojawia się wzmianka o czyjejś śmierci, to w znakomitej większości przypadków dotyczy osobistości znanych (między innymi Marysia Ajzensztadt, Roman Kramsztyk, Icchak Giterman) $)^{31}$. Odstępstwo od tej reguły stanowią zapisy Abrahama Lewina, który skrupulatnie odnotowywał szczegóły morderstw, między innymi współudział żydowskich prostytutek i sutenera, dzięki czemu „opowiedziana historia traci swą jednoznaczną wymowę, wymyka się martyrologicznemu schematowi, stając się przez to jeszcze bardziej przerażająca. Odsłania prawdę o dzielnicy zamkniętej, w inny sposób trudno dostępną czy wręcz nieosiągalną" 32 . Relacja Lewina przyjmuje formę zeznania, które mogłoby stanowić dowód w sprawie, gdyby takowa się odbyła. Jednak w czasie anomii próby rekonstrukcji faktów na podstawie zeznań świadków i materiału dowodowego, prowadzące do wskazania winnych oraz osądzenia ich, nie mogły się powieść:

Uśmiercanie na taką skalę było nie tylko czymś niewyobrażalnym, w co nie mogły do końca uwierzyć same ofiary. Masowa śmierć, zadawana metodycznie, na zimno, w ramach zbiurokratyzowanych procedur - wymykała się także zindywidualizowanemu opisowi. Wizerunek zbiorowego mordu jest jakby zatarty, brak w nim wyraźnego konturu, zbliżeń, charakterystycznych szczegółów.

28 Tamże, s. 71.

${ }^{29}$ Zob. tamże, s. 86.

30 Tamże, s. 61.

${ }^{31}$ Zob. J. Leociak: Tekst wobec Zagłady. O relacjach $z$ getta warszawskiego. Wrocław 1997, s. 205-212.

${ }^{32}$ Tamże, s. 215. 
Ujawnia raczej typowość niż wyjątkowość, raczej powtarzalność niż jednostkowość. Ofiary, pozbawione przez oprawców tożsamości, najczęściej pozostawały bezimienne również w relacjach świadków i ocalonych ${ }^{33}$.

Przeczytać dzienniki i egodokumenty z gett, mając na uwadze, że każde z istnień zasługiwało na ochronę, a po wojnie nie udało się ukarać sprawców i upamiętnić wszystkich ofiar, to jeden z najważniejszych postulatów zwrotu forensycznego. Sztuka Rosenstein, akcentując konieczność domagania się sprawiedliwości forensycznej, która gwarantowałaby zbliżenie ludzi, zwierząt i roślin, upomina się także o to, co słabe i kruche. Stawiam tezę, że surrealny rodowód tej twórczości w połączeniu z doświadczeniem Zagłady spowodował wyczulenie artystki na zjawisko relegowania niektórych istnień poza wspólnotę, której członkom należy się pamięć, oraz pozwolił zrewidować pogląd na ludzką hegemonię w momencie kryzysu ekologicznego. Poezja Rosenstein, sondując problemy, których eskalację przyniosły pierwsze dekady XXI wieku, antycypuje konieczność krytyki antropocentryzmu oraz poszukiwania nowych form kohabitacji ludzi i nie-ludzi. Projekt lektury, który tu przedstawiam, wiąże się z przekonaniem o prekursorstwie tej autorki i jej intuicji w kwestii świadomości nekroekologicznej. Poezja i sztuka, w których doświadczenie Zagłady rozpisane jest na poszczególne sekwencje obrazów, nie pozostawiają wątpliwości co do skuteczności angażowania czytelnika/widza za pomocą nastrojów i afektów. Oglądając portrety rodziców poetki, czuje się złość, gniew, współczucie, w końcu, opisywany przez Felski, szok, którego podstawą jest świadomość pogwałcenia prawa i niespełnienia warunków ochrony ludzkiego życia. Natomiast czytając liryczny pamiętnik (tak można traktować kolejne, wydawane dość regularnie tomy poetyckie), ujawniający poszczególne odsłony doświadczenia samotności, opuszczenia, w końcu rozpadu (znamionującego kondycję psychiczną i fizyczną), pamiętać trzeba o wychyleniu tej poezji w stronę posthumanizmu i regule szacunku: „Każde miejsce na ziemi jest tak samo wąskie. / Każde można poszerzyć o nieistnienie" (Międzysen, WS, s. 36). Formuła ta, nosząc znamiona oksymoronu, najpełniej wyraża konieczność pamięci i troski o tych, którzy w danym momencie historycznym zostali pozbawieni (w wyniku niesprzyjającego układu politycznego lub partykularnych interesów) szansy upamiętnienia lub obrony.

Rosenstein kilka lat przed Jeanem-François Lyotardem określiła Zagładę jako trzęsienie ziemi ${ }^{34}$ („Idę przez trzęsienie. Epicentrum we mnie” - Bez nikogo, WS, s. 154), co miało obrazować zarówno jej osobistą sytuację, jak i kondycję środowiska po katastrofie ${ }^{35}$. Korpus praktyk, które wyszczególnione zostały w jej poezji

33 Tamże, s. 212.

34 Zob. J.-F. Lyotard: Poróżnienie. Przeł. B. Banasiak. Kraków 2010, s. 69.

35 Zob. J. MaŁczyński: Krajobrazy Zagłady. Perspektywa historii środowiskowej. Warszawa 2018 
(łącznie z dbaniem o dobro planety, zwierząt i najbliższych), można nazwać, za Sendyką, kuratorskimi ${ }^{36}$ (badaczka przeciwstawia im działania zarezerwowane dla funkcji kustosza). Ich zakres okazuje się szeroki i obejmuje interwencję, diagnostykę, prewencję i kontrolę, a także działania wychowawczo-resocjalizacyjne. Tak sprofilowane zadania tej poezji świadczą też o tym, że celem jest tu angażowanie i forsowanie nowej wizji wspólnoty.

\section{Poezja w działaniu}

Ryszard Matuszewski, podsumowując poetyckie dokonania 1972 roku na łamach „Miesięcznika Literackiego”, odnotował (obok tomów Heleny Komorowskiej i Łucji Danielewskiej) debiut Erny Rosenstein:

[...] Ślad Erny Rosenstein, tom wierszy pióra wybitnej malarki, jest książką znaczącą, której ukazanie się ma swoją wagę tak moralną, jak artystyczną, mimo iż trudno w tym - formalnie biorąc - debiucie widzieć zapowiedź jakiejś kontynuacji. Po prostu to świadectwo musiało być dane, ten „ślad” musiał być odciśnięty. Wiersze Erny Rosenstein, artystycznie dojrzałe, zamknięte w oszczędny kształt, którego nie wahałbym się nazwać nowoczesnym klasycyzmem awangardowej proweniencji, a którego oblicze wyznaczają zarówno nazwiska Przybosia i Różewicza, jak Herberta, mówią o doświadczeniach epoki, doświadczeniach, które w każdym człowieku mojej przynajmniej generacji muszą budzić największy odzew ${ }^{37}$.

Uwaga o efemeryczności poetyki okazała się nietrafiona, jednak jest cenną wskazówką do rekonstrukcji światopoglądu krytyka, który mianując ją sukcesorką męskich wzorców, nie brał pod uwagę możliwości wypracowania przez Rosenstein oryginalnego idiomu. Celniejsze uwagi poczynił recenzujący Wszystkie ścieżki Paweł Dybel, pisząc o zasadzie „poetyckiej kulminacji - potęgowania określeń rzeczy do momentu niewyrażalności, do osiąganej granicy, poza którą nie ma już przejścia”" ${ }^{38}$. Zauważył także „dynamiczne rozumienie przez poetkę jej pojęcia »nicości«, co sprawia, że nie jest ona pustym niczym, ale wyczuwa się ją podskórnie w każdym niemal wierszu, zdaniu, słowie. Jest ukrytym ośrodkiem, ku któremu dążą i skąd wywodzą się wszystkie ścieżki życia, problemem, który autorka pragnie uchwycić i wyrazić w jego przemienności" ${ }^{39}$.

\footnotetext{
${ }^{36}$ Por. R. Sendyka: W imię zmartych..., s. 85.

37 R. Matuszewski: Wszyscy pisza wiersze. „Miesięcznik Literacki” 1973, nr 12, s. 57.

38 P. Dy bel: Pęknięty czas..., s. 122.

39 Tamże.
} 
Obaj krytycy konsekwentnie nie napisali, jakie wydarzenie wyznaczyło kluczowe dominanty tematyczne oraz bezkompromisowy sposób kolekcjonowania przez Rosenstein emocji i opracowywania ich w formie mgławicowych obrazów. Matuszewski docenił wagę moralną debiutu ${ }^{40} \mathrm{i}$ choć wybrał w swoim omówieniu jedne z najlepszych wierszy, zdecydował się na umieszczenie poezji Rosenstein $\mathrm{w}$ kontekstowej ramie $\mathrm{w}$ obawie przed możliwością przecenienia jej poetyckich umiejętności (wyraźnie wskazał bowiem domenę jej działań).

Wnikliwszymi komentatorkami jej dorobku okazały się Bożena Kowalska i Hanna Ptaszkowska, które (każda w swoim stylu) podkreśliły wspólne poezji i sztuce dominanty tematyczne, rozpiętość między „światłem i cieniem,

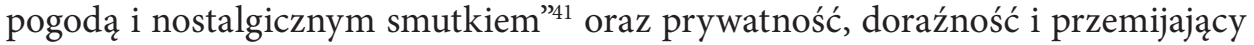
kontakt $\mathrm{z}$ artystą ${ }^{42}$. Ptaszkowska dodaje: „Na taką bezinteresowność umie zdobyć się dziecko i w tym sensie o malarstwie Erny Rosenstein możemy powiedzieć, że niesie w sobie dziecięcą, nie zafałszowaną prawdę"43. Uchwycenie interferencji między malarstwem, obiektami surrealnymi a poezją jest kluczową zasadą poznania tej ostatniej, o której zdawkowo wypowiedział się Matuszewski.

Kowalska, podejmując próbę scharakteryzowania dorobku Rosenstein w kilku formułach, za jego główne atuty uznała wieloznaczną metaforykę, aluzyjność i „ekscytujące wyobraźnię niedopowiedzenia”"44. Sama artystka pojmowała poezję, podobnie jak rysunki, jako punkt odniesienia do dalszych poszukiwań formalnych zdających raport $\mathrm{z}$ tęsknot, obaw i lęków ${ }^{45}$ :

Ja z wnętrza wydobywałam zawsze coś, co dla mnie samej stanowi tajemnicę. Nie wiem, co za chwilę ze mnie wyjdzie. W sposób irracjonalny raczej wiedziałam, że istnieje we mnie coś, co się chce ujawnić i ja tylko mogę to zobaczyć i wyrazić. Jeśli zaś patrzę na płótno, wydaje mi się również, że to już tam istnieje, tylko muszę je ujawnićt ${ }^{46}$.

Z tej niepełnej rekonstrukcji recepcji jej sztuki wynika znacząca polaryzacja dwóch stanowisk krytycznych: pierwsze (Matuszewski) docenia nominalną,

${ }^{40}$ Matuszewski wśród wierszy wartych odnotowania wymienia Protezy i Deklarację, w których zaszyfrowane zostały reakcje na wydarzenia Marca '68. Zob. TenżE: Wszyscy pisza wiersze..., s. 57.

${ }^{41}$ B. Kowalska: Uzupetnienia. W: Erna Rosenstein..., s. 41.

${ }^{42}$ H. Ptaszkowska: (2). W: Erna Rosenstein..., s. 42. Przedruk tej wypowiedzi pochodzi z 6. numeru „Poezji” z 1967 r.

43 Tamże.

${ }^{44}$ B. Kowalska: Uzupetnienia..., s. 39.

${ }^{45}$ Celnie wyraziła to Hanna Ptaszkowska, pisząc o spuściźnie plastycznej Rosenstein: „Mimo że osobista emocja i prywatna fantastyka staje się zobiektywizowanym faktem malarskim - obraz nie traci charakteru intymnej notatki i marginalnego śladu" (H. PтAszkowska: (2)..., s. 43).

${ }^{46}$ Na pewno mu nie przeszkadzałam. Rozmowa z Erna Rosenstein. [Rozmawiał Józef Baran]. W: Erna Rosenstein..., s. 78-79. 
a drugie (Ptaszkowska, Kowalska, Dybel) czasownikową wartość twórczości Rosenstein. Jej przypadek pokazuje, że nowatorstwa nie dyskredytują powinowactwa i nawiązania do innych artystów, ponieważ, jak pisze Kowalska w kontekście podobieństwa postawy autorki Śladu do poczynań Paula Klee, „Nawet jeśli sięga artystka po to, co już w sztuce było, po rzeczy zawidziane - i tak nie są to już one, ale ich nowe kreacje, przetworzone wyobraźnią i dotknięciem jej dłoni ${ }^{\prime \prime 7}$. Ważniejsze jest więc zobaczenie w niej poetki/plastyczki, której sztuka działa (i oddziałuje), niż poszukiwanie źródeł twórczości i skrupulatne wyszczególnianie artystycznych antenatów.

W twórczości Rosenstein doświadczenia Zagłady i Marca '68 pozostają $\mathrm{w}$ ścisłej zależności (drugie $\mathrm{z}$ nich spowodowało erupcję talentu literackiego ${ }^{48}$ ). Można by pokusić się o stworzenie listy powracających obrazów i fraz (w tomie wybranych wierszy pod niektórymi widnieje dokładna data powstania), jednak przyniesie to niewielki pożytek dla zrozumienia fenomenu tej poezji i braku miejsca dla Rosenstein w powojennych syntezach.

Celniejsze okazuje się podjęcie, za Ritą Felski, próby scharakteryzowania „literatury w użyciu", która, jak przekonuje badaczka, oddziałuje na czytelnika za sprawą dwóch rozbieżnych sposobów odbioru - oczarowania i szoku: „Oczarowanie, posiadając coś z instynktowności szoku, nie ma nic z jego poruszającego i konfrontacyjnego charakteru"49. Autorka Śladu oczarowuje, zdaniem Kowalskiej, samą poetyką i melodyjnością ${ }^{50}$, tworząc misterny świat odwzorowywany w dwóch różnych mediach (malarstwie i poezji). Jednak, mimo że Felski określa efekty szoku jako niepewne, chwiejne i trudne do wyskalowania, istnieje tabu, którego złamanie każdorazowo wywołuje szok:

Tak długo, jak będziemy skłonni do uników, eufemizacji i zaprzeczenia, tak długo, jak będziemy wzdragać się przed tym, co przypomina o materialności i śmiertelności naszej egzystencji jako kruchego połączenia krwi, kości i tkanek, w sztuce zawsze będzie miejsce dla szoku ${ }^{51}$.

${ }^{47}$ B. Kowalska: Uzupetnienia..., s. 38.

${ }^{48}$ Poetka w rozmowie z Józefem Baranem wyznała, że dzięki namowom męża, Artura Sandauera, oraz na skutek wydarzeń Marca '68 zdecydowała się zmienić formę artystycznej wypowiedzi, a także opublikować powstałe wtedy wiersze: „A tamto [twórczość poetycka - A.J.] było jakąś moją bardzo osobną twórczością i pewnie nigdy nie wyszłabym z tym na zewnątrz, gdyby nie sugestia Artura. Ale to było już znacznie, znacznie później. Jak się zebrało mnóstwo emocji, których nie mogłam inaczej wyrazić niż poprzez poezję. Po roku 1968, kiedy wielu przyjaciół wyjechało, kiedy poczułam się zbulwersowana wieloma sprawami - powstało dużo wierszy. Wtedy Artur namówił mnie do ich wydania w tomiku. Na pewno mu nie przeszkadzałam" (Na pewno mu nie przeszkadzałam..., s. 72).

${ }^{49}$ R. Felski: Literatura $w$ użyciu..., s. 64.

${ }^{50}$ Por. B. Kowalska: Uzupetnienia..., s. 40.

${ }^{51}$ R. Felski: Literatura $w$ użyciu..., s. 143. 
Szokujące są przede wszystkim naturalistyczne autoportrety Rosenstein, które korespondują z autocharakterystykami Leonory Carrington, informującej o braku uzębienia i odcinającej się od przypisywanej jej w młodości roli seksownej muzy ${ }^{52}$ :

Chybaś tu z rzeźni - ogryzek.

Chyba wiatr ci powyrywał włosy

albo mole wyżarły.

Tak biczowana zmarszczkami

jeszcze wyszłaś z lustra?

$[\ldots]$

Bardziej byłabyś, gdyby cię nie było.

SGM, s. 54

Drugi obszar, komplementarny wobec rozpadającej się powierzchowności, stanowi wnętrze ukazane jako wyludniona komora:

Zielskiem zarosły mi rygle.

Jestem w futrach najgłębszej piwnicy.

Słoiki pełne marzeń toczy robactwo.

Leżą zapasy słów, z których wyparowało życie.

Pudełka bez niczyjej kontroli.

Rdza.

Konserwy jutra

w nylonach z dziur i nicości,

w kawałkach aureoli...

Pieczęć na strup.

WS, s. 74

Ten abiektalny obraz, będący ekwiwalentem doświadczenia Zagłady, przez zestawianie zniszczonych, nieprzydatnych przedmiotów, które dawno utraciły wartość, jest wyznacznikiem zdegradowanej wyobraźni Rosenstein oraz stanowi punkt wspólny poetów wyczulonych na jakość i materialność przedmiotów, którzy stosują wyliczenie jako wyznacznik elegijności: Stanisława Grochowiaka i Mirona Białoszewskiego. Felski, polemizując z tezą o możliwości oddziaływania tekstów literackich jedynie w momencie ich pierwszego ukazania się, odrzuca ugruntowany sposób myślenia, który zakłada, że szokowanie jest synonimem nowego, i konceptualizuje ich potencjał w postaci bomb zegarowych, ładunków nafaszerowanych materiałem wybuchowym ${ }^{53}$. Wiersze Rosenstein stanowią rodzaj „podróżników w czasie" (to także określenie zaproponowane przez badaczkę), którzy trafili na

\footnotetext{
${ }^{52}$ Zob. A. Taborska: Spiskowcy wyobraźni. Surrealizm. Gdańsk 2013, s. 230.

${ }^{53}$ Por. R. Felski: Literatura w użyciu..., s. 127-128.
} 
odpowiedni moment nie tylko ze względu na komparatystyczne badania, wykazujące równoległość awangardowych poczynań artystów zza żelaznej kurtyny wobec twórców zachodnich, lecz również z uwagi na współczesne tendencje do detronizacji podmiotów na rzecz siatki nie-ludzkich aktorów.

Kluczowym, choć niewyjaśnionym przez Matuszewskiego, spostrzeżeniem jest to dotyczące wspólnej poetom wstrzemięźliwości emocjonalnej oraz (co sugeruje zestawienie Rosenstein z Herbertem) szyfrowanie współczesności i kreowanie światów lirycznych $\mathrm{w}$ pozornym zawieszeniu temporalnym. Jeśli pokusić się o wskazanie dwóch chwytów organizujących wiersze Rosenstein (komplementarnych wobec formuł krytycznych Matuszewskiego i Dybla), byłyby to nastrój (Stimmung) oraz afekt (autor Dylematów demokracji wspomina o somatycznym odczuwaniu pozornej nicości, co koresponduje z wizualizacją afektu, którą jest nakłuwanie skóry ${ }^{54}$ ukazane na obrazie Uderzenia ${ }^{55}$ z 1968 roku).

Pamiętając jednak o wskazówce Jill Bennett, która twierdzi, że żadne dzieło, nawet to afektywnie oddziałujące na odbiorcę, nie jest nośnikiem czy śladem cudzej traumy, trzeba odrzucić teorie głoszące możliwość zapośredniczenia tego, co traumatyczne w sztuce i literaturze. Badaczka w artykule Wnętrza, zewnętrza: trauma, afekt $i$ sztuka przekonuje, że „afekt nie podlega wstępnemu kodowaniu ze strony systemu przedstawieniowego pozwalającego na odczytanie obrazu »o traumie«, a następnie na doświadczenie obrazu jako traumy wtórnej (secondary trauma)" ${ }^{\prime \prime}$. Stawką afektywnej estetyki nie jest zmuszenie odbiorcy do identyfikacji ze straumatyzowanym podmiotem, lecz objawienie, które pochodzi z cielesnego afektu zgodnie z zasadą, że „Prawda odsłania się ciału, nigdy zaś obserwatorowi” ${ }^{57}$. Bennett podkreśla, że konieczne jest „widzenie z wnętrza ciała, dzięki czemu bardziej dogłębnie widzi się prawdę"58. Akt odbioru estetycznego nie polega na aktualizowaniu mechanizmu wtórnej traumy, ale na otwarciu nowego pola wymiany i odwołaniu do bieżących wydarzeń. Dlatego w Skale poetka odrzuca substancjalność skały na rzecz „sieci gęstniejącej”, wiążącej krzywdy czasu Zagłady i współczesności:

Ja - jestem już nie skała - sieć gęstniejąca,

lustro dla nóg po mnie idących

${ }^{54}$ Jill Bennett podkreśla, że obraz przerwanej skóry pojawia się w pracach artystów zajmujących się pamięcią zmysłową. Jako przykład podaje Parting Embrace Dennisa Del Favera. Skłonność do takiego obrazowania wykazują często artyści, którzy przepracowują przemoc cielesną. Zob. J. Bennett: Wnętrza, zewnętrza: trauma, afekt i sztuka. Przeł. A. Kowalcze-Pawlik, T. Bilczewski. W: Pamięć i afekty. Red. Z. Budrewicz, R. Sendyka, R. Nycz. Warszawa 2014, s. 174.

${ }^{55} \mathrm{Na}$ temat strategii afektywnych w sztuce Rosenstein zob. D. Jarecka, B. Piwowarska: Erna Rosenstein..., s. 219-236.

${ }^{56}$ J. Bennett: Wnętrza, zewnętrza..., s. 164.

57 Tamże, s. 170.

58 Tamże. 


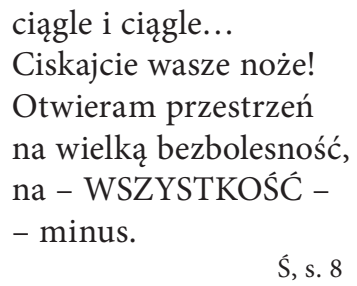

W działaniach artystycznych Rosenstein dochodzi do sprzężenia tego, co ludzkie, i tego, co nie-ludzkie, na dwóch polach: w asamblażach i poezji manifestującej uznanie dla wszystkiego, co kruche i słabe (porzuconych przedmiotów i zwierząt), na długo przed nazwaniem Zagłady punktem krytycznym, na skutek którego konieczne stało się wyszczególnienie nowych obszarów katastrof (między innymi ekocydu, terracydu i planetocydu). Redukcja roli ludzkich aktorów postępuje w tej poezji stopniowo, lecz konsekwentnie. Zarzewiem wiary w nowy ład jest przeświadczenie o emancypacyjnym potencjale przedmiotów zdolnych zaburzyć dotychczasowe status quo, jak również wyrazić niewyrażalne (strategia ta okaże się kluczowa w procesie dowartościowywania artefaktów po Zagładzie ${ }^{59}$ i materialności jako sposobu przepracowywania traumy ${ }^{60}$ ), co wskazuje na surrealistyczny rodowód praktyk Rosenstein:

Zainteresowanie surrealistów rzeczami wzięło się z przekonania, że nadrzeczywistość tkwi w rzeczywistości. Surrealistyczne przedmioty były owej innej rzeczywistości zwiastunami. Stanowiły dowód na moc wyobraźni, wyraz ciekawości nieograniczoną ilością rozwiązań możliwych. Wyzwalały rzeczy z pęt narzuconej im użytkowości. Wywoływały w widzu niepokój ${ }^{61}$.

To pokrewieństwo nie jest przypadkowe; poetka w 1938 roku zwiedziła Międzynarodową Wystawę Surrealizmu w Galerie Beaux-Arts w Paryżu'b2 a jej reminiscencje, objawiające się w dalszych etapach twórczości, zbadała skrupulatnie Dorota Jarecka, wśród inspiracji wymieniając między innymi Téléphone-homard Salvadora Dalego (jego odpowiednikiem był niepokojący telefon-destrukt) i Śniadanie $w$ futrze Méret Oppenheim (wariant biżuteryjny - bransoletka z futrem powstała jako przedmiot do kolekcji domu mody Elsy Schiaparelli mógł być powodem zainteresowania Rosenstein sztuką recyklingową i podjęcia wyzwania stworzenia biżuterii wykonanej własnoręcznie z odpadów).

${ }^{59}$ Zob. B. Shallcross: Rzeczy i Zagłada. Kraków 2010, s. 19-25.

${ }^{60}$ Zob. P. MożDżyŃski: Inicjacje i transgresje. Antystrukturalność sztuki XX i XXI wieku w oczach socjologa. Warszawa 2011, s. 97-105.

${ }^{61}$ A. Taborska: Spiskowcy wyobraźni..., s. 179.

${ }^{62}$ Zob. D. Jarecka, B. Piwowarska: Erna Rosenstein..., s. 16. Fakt ten wspomina również Urszula Usakowska-Wolff - przyjaciółka artystki. Zob. Taż: Odbicia na płótnie, niecichnace słowa. „Midrasz” 2014, nr 1, s. 29. 
Surrealizm jako ruch emancypujący wyobraźnię wymagał zrewolucjonizowania spojrzenia na to, co pozornie znane, w celu odkrycia nadrzeczywistości. Poezja wykorzystująca konwencje surrealistyczne może, jak przekonuje z powodzeniem artystka, zbliżyć się do doświadczenia Zagłady. Ta odpowiedniość wynika przede wszystkim z odwrócenia dotychczasowych wektorów nawiązań i inspiracji. René Passeron twierdzi, że XX wiek przyniósł obrazy, których groza unieważnia dotychczasowe wyobrażenia makabry prekursorów surrealizmu ${ }^{63}$, stąd puenta Po wszystkim:

Otulę się w cień,

okryję ciepłą powieką,

zamieszkam w przydrożnej chwili...

Tam na byle jakim kalendarzu

ukrzyżowano nawet motyla,

aby zapomnienia swego strzegł

i nawet posłoneczną plamę,

która odtąd się cofa...

[...]

Oto latarnia spala samotność na światło,

wbita w ziemię,

twarda i pozytywna jak grób...

Teraz już, choćby pękła sama północ i wylała noc

i choćby krzyk bardziej jeszcze od niej nocny...

Znam to...

Widziałam taką jawę, że im zrówna...

[...]

Ś, s. 41

Mimo że zamykająca wiersz deklaracja wyłamuje się z porządku surrealnego obrazowania, zaburzając efekt poetyckiej kulminacji (o którym wspominał Dybel), przypieczętowuje surrealność tego, co nie mogłoby konkurować z wytworami wyobraźni Hansa Memlinga, Hieronima Boscha, Francisca Goi lub Gustava Klimta.

\section{Ratunkiem jest tylko poezja}

Berel Lang, zastrzegając, że „dla określonej tematyki literackiej dyskurs figuratywny może być niewłaściwym, a faktycznie zupełnie nieodpowied-

${ }^{63}$ Zob. R. Passeron: Encyklopedia surrealizmu. Przeł. K. Janicka. Warszawa 1993, s. 25. 
nim medium" ${ }^{\prime 4}$, konsekwentnie odmawia poezji wartości epistemologicznej i zastrzega, że jest ona nieodpowiednią formą do narratywizacji doświadczenia Zagłady. Podstawą jego podziału na wartościowe pisarstwo historyczne/dokumentalne i figuratywne/fikcyjne jest wiara $\mathrm{w}$,»moralne korelaty - czyli punkty, w których przecinają się wartości moralne i literackie, kiedy moralny charakter tematu literackiego narzuca ograniczenia na formalne cechy tekstu. Na tej podstawie można wyciągnąć wniosek, że fundamentalna różnica pomiędzy pisarstwem historycznym a literaturą piękną tkwi w cechach moralnych"65. Literackość jest według badacza niestosowna ze względu na odwodzenie czytelnika od konkretów (dla Langa pierwszorzędne znaczenie mają fakty, liczby i daty) oraz akcentowanie estetyzacji. Postuluje on także konieczność istnienia miejsc niedookreślenia, co wiąże się z nakazem utrzymania zasady „zakazu reprezentacji”:

Ekstremalny charakter nazistowskiego ludobójstwa jest oczywisty, nie wymaga dodatkowych wyjaśnień. Można by było przedstawić je za pomocą zwykłych poetyckich lub prozatorskich środków, które - gdyby działały we właściwy sobie sposób - „symbolizowałyby” ludobójstwo, przedstawiałyby cechy, dzięki którym czytelnik mógłby je sobie pełniej wyobrazić lub uświadomić. Jednak w najlepszym wypadku pisarz rozwodziłby się tu nad rzeczą samą przez się oczywistą: jakie zabiegi literackie mogą pełniej „uświadomić” fakty przynależące do tego wydarzenia? W najgorszym to, co napisał, nie dorównywałoby nawet intensywności owych faktów. A zatem piszmy, zakładając pewne wydarzenia, traktujmy jak rzecz oczywistą ich istnienie i ekstremalny charakter nawet jeżeli oznacza to, że czytelnik sam będzie musiał uzupełnić historyczne szczegóły i wyobrazić sobie reakcje, których sam tekst nie dostarcza ${ }^{66}$.

W rozważaniach Langa można jednak dostrzec dwie niekonsekwencje. Pierwsza dotyczy zakazu ujawniania tego, co powinno zostać utajone, który zostaje przez badacza uchylony w momencie konfrontacji kłamstwa jako szczególnej figury retorycznej z możliwościami języka figuratywnego, ponieważ „celem języka figuratywnego, a być może i wszystkich języków, było odkrywanie i podkreślanie, a nie likwidowanie, pomniejszanie czy niszczenie"67. Druga natomiast dotyczy deprecjonowanych zasad dyskursu figuratywnego polegających na personalizowaniu wydarzeń bezosobowych i zbiorowych oraz dehistoryzowaniu i generalizowaniu wydarzeń określonych i przypadkowych ${ }^{68}$.

${ }^{64}$ B. Lang: Nazistowskie ludobójstwo. Akt i idea. Przeł. A. Zı̨̨вıńsкa-Wıтeк. Lublin 2006, s. 160.

${ }^{65}$ Tamże, s. 136.

${ }^{66}$ Tamże, s. 119.

67 Tamże, s. 116.

${ }^{68}$ Lang pisze: „Poprzez uznanie możliwości alternatywnych, figuratywnych perspektyw, pisarz podkreśla proces reprezentacji i swoją osobę jako elementy reprezentacji - co jest dalszą redukcją tego, co dla tematu, jakim jest nazistowskie ludobójstwo, pozostaje sprawą podstawową; 
Zasada ta w przywoływanej przez Langa poezji Paula Celana manifestuje się przez wierność jed nostkowej biografii. Badacz zastrzega wręcz, że konieczność poznania biografii poety „jest niezbędna dla doświadczenia siły tkwiącej w poematach"69.

W tak zarysowanym projekcie wierności faktom i dowartościowania „kroniki zdarzeń" 70 , której ustalenie pozostaje, według autora Nazistowskiego ludobójstwa, jednym z najważniejszych zadań całego pisarstwa o Szoa, nie ma miejsca na to, co w poezji o Zagładzie najważniejsze: obrazy afektywnie poruszające czytelnika ${ }^{71}$ oraz całą sferę emocji ocalałych, które poezja transmituje. Lang, podejrzliwy wobec sztuki słowa jako fałszującej doświadczenie, uznaje jednak prymat Celana wśród innych podejmujących temat Holokaustu. Niekonsekwencja wynikająca $\mathrm{z}$ dodatniego wartościowania dyskursu figuratywnego (przy jednoczesnej świadomości jego pułapek i mielizn) ma swoje źródło w afektach, których badacz nie może zredukować, choć asekuruje się dodaniem do opinii przysłówka „prawdopodobnie". By utrzymać w mocy forsowaną tezę o niespełnianiu przez poezję zadań pisarstwa historycznego, Lang dodaje (usprawiedliwiająco), że odwołania do prawdziwych imion (Małgorzaty i Sulamity) w Fudze śmierci można traktować jako walor referencji ${ }^{72}$.

Trafniejsze rozpoznania względem poezji tego autora proponuje Hans Ulrich Gumbrecht, który próbując odpowiedzieć na pytanie: „Jak mamy rozumieć świat poetycki Celana oraz intensywność jego obrazowania?”, stwierdza:

Liczne zachodzące na siebie elementy tego świata nie tworzą spójnej całości ani niczego w rodzaju „systemu”. Zamiast tego, gdy czytamy wczesne teksty poety, czujemy się tak, jakbyśmy znajdowali się w jakimś polu siłowym. Z jednej strony, obecność centralnego motywu naczynia obiecuje bezpieczeństwo - pełnię

poza tym "perspektywa« indywidualna jest w najlepszym wypadku niestosowna. Wydaje się, że znaczenie pewnych tematów może być zbyt szerokie lub głębokie, aby pozostawiać je indywidualnemu punktowi widzenia, zbyt ekstremalne i zbyt istotne, aby można było utrzymać koncepcję istnienia wielu możliwości. Pod takim naciskiem założenie o iluminacji zwykle przyznawane aktowi pisania (jakiegokolwiek pisania) zaczyna tracić swoją siłę" (tamże, s. 155-156).

69 Tamże, s. 150.

70 Tamże, s. 97.

${ }^{71}$ Alvin H. Rosenfeld, broniąc swobody twórczej, która wykracza poza nakaz wierności faktom, pisze: „Przyglądając się powieści o Holokauście można zauważyć, że największe wrażenie na czytelniku robi ona właśnie wtedy, gdy odchodząc od tradycyjnych standardów powieściopisarstwa zaczyna zbliżać się do poezji. Po lekturze pozostaje w nas często nie rozwój akcji czy opisy postaci, ale sceny, w których wyrażony zostaje pewien nastrój za pomocą kilku wspaniałych obrazów, wyrazistych jak fotografie, które tak poruszyły Carla Leviego" (A.H. Rosenfeld: Podwójna śmierć. Rozważania o literaturze Holocaustu. Przeł. B. Krawcowicz. Warszawa 2003, s. 123). Badacz wymienia przede wszystkim pola ludzkich głów z Krwi nieba Piotra Rawicza, martwe dzieci wynoszone z wagonów ,jak kurczaki” z opowiadania Proszę państwa do gazu Tadeusza Borowskiego i rzeź motyli z Ostatniego sprawiedliwego André Schwarz-Barta.

${ }^{72}$ B. LANG: Nazistowskie ludobójstwo..., s. 150. 
materialnego życia, którego ludzka egzystencja może się trzymać, w czasie gdy niekontrolowane siły i ruchy nieustannie zagrażają jej wykolejeniem ${ }^{73}$.

Uczucie bycia $\mathrm{w}$ polu siłowym, a także odnotowana ambiwalencja $\mathrm{w}$ stosunku do obrazów są bardziej pożądanym efektem niż próba potraktowania wiersza jako źródła wiedzy historycznej (co ważne, nawet Lang ulega iluzji braku konwencji w pisarstwie Borowskiego, dowartościowując jego „koncepcję zobiektywizowanych [...] szczegółów"74, co oczywiście w świetle nowych odczytań okazuje się błędnym rozpoznaniem) oraz śledzenia odprysków przeszłości w postaci dat i imion, ponieważ dotyczą nastrojów, jakie wywołuje w czytelniku poezja o Zagładzie.

Gumbrecht, proponując nowy sposób opisu tekstów literackich, wyróżnia ich pojedyncze składniki (między innymi słowo, ton, rytm), które przykuwają uwagę i wpływają na sposób recepcji poszczególnych utworów. Oddziałujące na czytelnika nastroje pozwalają na szczególnie intensywne i intymne przeżywanie odmienności (Alterität) ${ }^{75}$. Uwaga ta jest ważna, ponieważ to właśnie piętnowane przez Langa bliskość i jednostkowość doświadczenia, które transmituje wiersz, stają się gwarantem uobecnienia minionej rzeczywistości i dzięki temu doznania wrażenia bezpośredniości ${ }^{76}$. Badacz podkreśla, że jego metoda nie może zostać skodyfikowana, ponieważ warunkiem sukcesywnie przeprowadzonego czytania nastrojów jest nie tylko prześledzenie większej liczby tekstów w celu odtworzenia nastrojów historycznych sytuacji, lecz również bycie „osobiście dotkniętym od środka"77, afektywnie poruszonym:

„Czytanie nastrojów” to odkrywanie nastrojów w tekstach i innych artefaktach, afektywne i także fizyczne wchodzenie $\mathrm{z}$ nimi w bliski kontakt i wskazywanie na nie. Zrekonstruowanie historycznej genezy czy struktur przedstawiania wprawdzie też oczywiście nie zaszkodzi - ale tego rodzaju analizy pozostają drugorzędne. Chcemy przede wszystkim wskazywać na nastroje, odsłaniać potencjał nastrojów, wspierać, na ile się da, ich uzmysłowienie ${ }^{78}$.

Rosenstein, omijając pułapki, jakimi dla świadczącego o morderstwie są fakty ${ }^{79}$, które, o czym wspominała Felski, lokują jednostkowe zdarzenie w sze-

${ }^{73}$ H.U. Gumbrecht: Po roku 1945. Latencja jako źródło wspótczesności. Przeł. A. PAszkowSKA. Wstęp A. KRZEMiŃski. Warszawa 2015, s. 164-165.

${ }_{74}$ B. LANG: Nazistowskie ludobójstwo..., s. 147.

75 Por. H.U. Gumbrecht: Czytanie nastrojów. Jak można pomyśleć dziś rzeczywistość literatury. Przeł. A. Żychliński. W: Teoria - literatura - życie. Praktykowanie teorii w humanistyce wspótczesnej. Red. A. Legeżyńska, R. Nycz. Warszawa 2012, s. 164.

76 Por. tamże, s. 165.

77 Tamże, s. 171.

78 Tamże, s. 169-170.

${ }^{79}$ Rosenstein w rozmowie z Macużanką szczegółowo rekonstruuje zabójstwo rodziców: „Mężczyzna wymachiwał rękoma i nożem. Krzyczał, że jest wyprowadzony z »nerw«. Zachowy- 
regu podobnych, nieistotnych, bo powtarzalnych wydarzeń, intensyfikuje wrażenie bycia poruszoną, stosując skalę mikro oraz traktując krajobraz jako zaszyfrowaną wiadomość. Deskrypcja materialnych śladów łączy się w poezji autorki Śladu z praktykami odczytywania przyrody, która traci niewinność, ponieważ była niemym świadkiem zbrodni, a ruch materii, zachodzący w ramie, jaką jest $\mathrm{krajobraz}^{80}$, pozwala na ukazanie tropów zamordowanych oraz stanowi zarzewie wiary w zespolenie tego, co ludzkie, i tego, co nie-ludzkie:

Tędy biegli umierający,

siejąc po drodze krew.

Każda rozdarta chwila walczyła o wieczność.

Zostali w liściach.

W niewyraźności.

$\mathrm{W}$ migocie drzew.

Ich kroki powtarza trawa.

C, s. 85

Nie ulega wątpliwości, że strategia, którą wybrała Rosenstein, okazuje się skuteczniejsza niż próba dochowania wierności faktom. Ufając w ich moc, wiążącą ludzi na powrót we wspólnotę, poetka utraciłaby możliwość szokowania czytelnika (na wielu poziomach) i wywoływania afektywnej reakcji współbycia z krzywdzonymi, ponieważ to właśnie impuls ciała stanowi punkt zapalny wszelkich praktyk przeciwdziałania przemocy i groźbie śmierci. Nieprzypadkowo w wywiadzie z Józefem Baranem mówiła: „Musi się być podszytym emocją, jeżeli w ogóle się dochodzi do twórczości" ${ }^{11}$. Podstawą nowych, postulowanych w jej poezji relacji ze zwierzętami i z roślinami są poczucie równości (stąd krytyka antropocentryzmu) oraz konieczność uchronienia środowiska przed degradacją, dlatego wyznanie poczynione w rozmowie z Łukaszem Guzkiem: „Nie można zamknąć się w sobie, nie można iść tylko w głąb siebie" ${ }^{2}$, traktować można jako jej artystyczny manifest. Przemianę sposobu postrzegania elementów nie-ludzkich i ich roli w poezji

wał się jak furiat. Wołał, że kobieta nachalnie domagała się obiecanego noclegu. Nasze zaufanie do niego upadło, ale co mieliśmy robić. Udawaliśmy, że wierzymy. Prosiliśmy, aby się uspokoił. Byliśmy jeszcze bardziej zdani na jego łaskę w kompletnych ciemnościach i na odludziu. Domagał się teraz, abym poszła z nim szybciej do przodu. Odnajdziemy wtedy lokum i wrócimy po rodziców. Miał w ręku duży, ostry nóż [podkr. - A.J.]. Krzyczał i groził. Matka po cichutku szepnęła do mnie: »Patrz, odciął mi palec«, ale ja tego nie zobaczyłam w ciemnościach. Pamiętam to jednak przez całe życie. Ojciec ukląkł przed nim. Prosił, aby nic mi złego nie zrobił i opiekował się mną. To był ostatni moment mojego kontaktu z rodzicami, jaki zapamiętałam" (To we mnie trwa... (rozmowa z Zenona Macużanka). W: Erna Rosenstein..., s. 52).

${ }^{80}$ Zob. R. Sendyka: Śledztwo i łowy. Nie-miejsca pamięci i krajobraz cynegetyczny. W: Poetyki ekocydu. Historia, natura, konflikt. Red. A. Ubertowska, D. Korczyńska-Partyka, E. Kuliś. Warszawa 2019, s. 88.

${ }^{81} \mathrm{Na}$ pewno mu nie przeszkadzałam..., s. 70.

${ }^{82}$ Rozmowa Łukasza Guzka z Erna Rosenstein. W: Erna Rosenstein..., s. 34. 
Rosenstein uchwycić można, zestawiając (co czyni również sama autorka w tomie wierszy wybranych) utwory o identycznych tytułach: Kamień. W pierwszym (z 1967 roku) kamień jest balastem, czymś, co przypomina o podrzędności i nierówności szans, stanowi także wyzwanie ze względu na konieczność samoidentyfikacji i ukonstytuowania własnej podmiotowości po katastrofie, w drugim (z 1974 roku) natomiast kamień po prostu jest, objawia się materialnie, perceptualnie i przeciwstawiony zostaje ludzkiej skończoności („Mięso to tampon pyłu” - WS, s. 153):

$[\ldots]$

W samej niesłyszalnej jego głębi

uderza serce ciszy.

Liczy.

Mam oczy białe.

Mam pamięć do tyłu.

Kolor mój gołębi.

Jestem niewidzialny z nawyku.

Zauważ mnie.

WS, s. 153

W jednym z wywiadów Robert Smithson, najbardziej znany przedstawiciel sztuki ziemi, określił się mianem entropologa ${ }^{83}$ - badacza entropii, śladów zanikania, rozpadu form, entropia bowiem, jak twierdził kodyfikator land artu, jest procesem, który daje najlepszy wgląd w sprawy ostateczne - śmierć i czas $^{84}$. Spiralna grobla - jego najbardziej znana rzeźba - skazana na nieuniknioną zagładę i podległa naturalnym procesom, najpełniej objawia to, co przeraża człowieka, ponieważ lokuje się poza skalą jego percepcji i podkreśla prymat zjawisk spoza "systemów zamkniętych”, a więc: utleniania, uwadniania, zwęglania, rozpuszczania, które sztuka modernistyczna odrzucała. Późna poezja Rosenstein sytuuje się w pobliżu działań przedstawicieli sztuki ziemi nie tylko ze względu na wpisaną w nią nietrwałość, lecz także śledzenie form zanikania ludzkiego podmiotu.

Rekonstruowana tu wyobraźnia forensyczna, mająca kluczowe znaczenie dla uchwycenia światopoglądu poetki, stanowi rękojmię $\mathrm{w}$ walce $\mathrm{z}$ procesem zapominania o „ludziach rzeźnych”, utraconych bezpowrotnie na skutek Zagłady (Targ, WS, s. 118), jak również zwierząt towarzyszących (kotów i psów) ${ }^{85}$.

${ }_{83}$ Zob. G. Dziamski: Awangarda po awangardzie. Od neoawangardy do postmodernizmu. Poznań 1995, s. 141.

${ }^{84}$ Por. tamże, s. 138.

${ }^{85}$ Przywiązanie Rosenstein do zwierząt ujawniło się także w anegdocie o Jonaszu Sternie, który, biorąc udział w jednym ze spływów, miał zapytać Stanisława Wiśniewskiego, czy Fredzio - kot pozostawiony pod opieką znajomych - tęskni za artystą. Komentująca tę anegdotę Anna MARKOWSKA puentowała: „Rosenstein miała bowiem pewność, że z takich właśnie drobiazgów można zbudować portret człowieka i portret artysty" (TAż: Język Neuera. O twórczości Jonasza Sterna. Cieszyn 1998, s. 104). 
Świadomość nekroekologiczna najpełniej objawia się w Przykazaniu, wierszu z debiutanckiego Śladu. To w nim praktyki charakterystyczne dla funkcji kustosza $^{86}$ „uwikłanego w maleńkie ojczyzny” (,jutro układają w słojach na półeczce, / w teczkach rozmowy i wzory" - Przykazanie, S, s. 22) przeciwstawione są działaniom globalnym. Redukowanie ich do lokalnie zorientowanych zajęć w skali mikro („wrosłeś teraz nogami w punkt jeden” - Przykazanie, Ś, s. 22) uniemożliwia zniesienie mocnego podziału i jednoznacznych kategoryzacji opierających się na opozycji żywe/martwe w odniesieniu do ciała pozbawionego czynności życiowych oraz dostrzeżenie potencjału nekrolatrii ${ }^{87}$ :

Twoja ziemia jest $\mathrm{z}$ tobą nie większa od stopy,

[...]

Jeśli ją nawet zgubisz, pójdzie za tobą jak pies...

Zmartwychpowstaje z każdego cmentarza.

Większa od niezobaczenia...

Jest.

$$
\text { S, s. } 22-23
$$

Wyobraźnia forensyczna stanowi formę ratunku przed zawłaszczającymi działaniami człowieka i wpisuje go w porządek kosmiczny, cykl, który nie uznaje wyjątków i wszystko zrównuje. Rosenstein, nadając przedmiotom i destruktom szczególne znaczenie, obdarzając je sprawstwem, a nawet wierząc $w$ ich utajone życie, zbliża się do rozwijającego się w latach 90 . nurtu estetyki relacyjnej, która, jak twierdzi Nicolas Bourriard, kładzie nacisk na działanie i uwalnianie sztuki z instytucjonalnych ram (muzeum, wystawy, określony protokół zachowań wobec dzieła), stąd hasło „Sztuka jest stanem spotkania”"8. Przedstawiciele tego nurtu (między innymi Gabriel Orozco, Jens Haaning), działając w przestrzeni publicznej, powodują za pomocą codziennych gestów zawiązanie relacji z momentalnymi obserwatorami.

W późnej poezji Rosenstein autonomizacja przedmiotów wynika z wiedzy o ludzkiej skłonności do destrukcji (genocyd i ekocyd), jednak brak ludzkich aktantów nie zwalnia ich z narzuconych im obowiązków. Mimo że koncert ze Śpiewu pojemników pozbawiony jest widowni, jej obecność staje się konieczna do zrozumienia nekrotycznej transformacji:

\footnotetext{
${ }^{86}$ Por. R. Sendyka: W imię zmarlych..., s. 85.

${ }^{87}$ Zob. E. Domańska: Nekros..., s. 292-296.

${ }^{88}$ N. Bourriaud: Estetyka relacyjna. Przeł. Ł. BiaŁkowski. Kraków 2012, s. 46.
} 
Ciężar... Ciężar... Ciężar...

Mówi milczenie rdzy.

Flaki dnia wczorajszego

spadają coraz niżej.

Kapie.

Nie ma dna.

Biją dni bez domu.

Trwa.

Pieśnią robaków

śpiewa nikomu...

...rdza.

TA, s. 23

Milczenie rdzy jest znaczące, porozumiewawcze, dlatego w Prawie bez słów inkorporowane matki mają nas przekonać, „że osobność to złudzenie. / Jesteśmy wszyscy jedno" (TA, s. 38). Proces przemian i bio-degradacji, jaki pojawia się w późnej poezji Rosenstein, nie jest czymś wyjątkowym; to prawo życia, które niespiesznie osuwa się w śmierć, zniszczenie. Według poetki nie można go lekceważyć, usuwać z pola widzenia, ponieważ zawsze konieczne jest scedowanie obowiązków na kuratora, który nie tylko doprowadzi śledztwo do końca, lecz również zinwentaryzuje resztki i sporządzi listy proskrypcyjne, obejmujące imiona zmarłych i przedmioty będące przez jakiś czas ich towarzyszami. W obliczu Zagłady i innych katastrof strategia ta wydaje się najbardziej rozsądna. Dla Rosenstein to właśnie wiersz pełni taką funkcję, stąd zawołanie z utworu Idzie: „Wstańcie rośliny, zwierzęta, ludzie. / Idzie wiersz. / Większy od słów” (TA, s. 40). To aż nadto, by uznać, że poezja faktycznie stanowi ratunek i pieczętuje ludzko-nieludzkie sojusze.

\section{Bibliografia}

Agamben G.: Co zostaje z Auschwitz. Archiwum i świadek. Przeł. S. Królak. Warszawa 2008.

BARANOWska M.: Surrealna wyobraźnia i poezja. Warszawa 1984.

Bennett J.: Wnętrza, zewnętrza: trauma, afekt i sztuka. Przeł. A. Kowalcze-Pawlik,

T. Bilczewski. W: Pamięć i afekty. Red. Z. Budrewicz, R. Sendyka, R. Nycz. Warszawa 2014, s. 145-179.

Bourriaud N.: Estetyka relacyjna. Przeł. Ł. BiaŁkowski. Kraków 2012.

Butler J.: Ramy wojny. Kiedy życie godne jest opłakiwania? Przeł. A. Czarnacka.

Warszawa 2011.

Domańska E.: Nekros. Wprowadzenie do ontologii martwego ciała. Warszawa 2017. 
Dybel P.: Pęknięty czas. „Twórczość” 1980, nr 6, s. 122-123.

Dziamski G.: Awangarda po awangardzie. Od neoawangardy do postmodernizmu. Poznań 1995.

Erna Rosenstein. Red. i układ graf. J. Снвовак. Kraków 1992.

Felski R.: Literatura w użyciu. Przeł. J. Borkowska, K. Dembowy, K. Ignaczak i in. Poznań 2016.

GŁowacka D.: Po tamtej stronie. Świadectwo - afekt - wyobraźnia. Warszawa 2016.

Gumbrecht H.U.: Czytanie nastrojów. Jak można pomyśleć dziś rzeczywistość literatury. Przeł. A. Żychliński. W: Teoria - literatura-życie. Praktykowanie teorii w humanistyce współczesnej. Red. A. LegeżyńsKa, R. Nycz. Warszawa 2012, s. 151-171.

Gumbrecht H.U.: Po roku 1945. Latencja jako źródło współczesności. Przeł. A. PaszKowsKa. Wstęp A. Krzemiński. Warszawa 2015.

JANICKA K.: Surrealizm. Warszawa 1985.

Jarecka D., Piwowarska B.: Erna Rosenstein. Mogę powtarzać tylko nieświadomie / I Can Repeat Only Unconsciously. Warszawa 2014.

Kornhauser J.: Awangarda. Strajki, zakłócenia, deformacje. Kraków 2017.

Krall H.: Zdążý przed Panem Bogiem. Hipnoza. Biała Maria. Warszawa 2013.

Lang B.: Nazistowskie ludobójstwo. Akt i idea. Przeł. A. ZięBińska-Witek. Lublin 2006. LeOCIAK J.: Tekst wobec Zagłady. O relacjach z getta warszawskiego. Wrocław 1997.

Lyotard J.-F.: Poróżnienie. Przeł. B. Banasiak. Kraków 2010.

MaŁCzyŃski J.: Krajobrazy Zagłady. Perspektywa historii środowiskowej. Warszawa 2018.

Markowska A.: Język Neuera. O twórczości Jonasza Sterna. Cieszyn 1998.

Matuszewski R.: Wszyscy pisza wiersze. „Miesięcznik Literacki” 1973, nr 12, s. 44-57.

MożDŻyŃsKi P.: Inicjacje i transgresje. Antystrukturalność sztuki XX i XXI wieku w oczach socjologa. Warszawa 2011.

Passeron P.: Encyklopedia surrealizmu. Przeł. K. Janicka. Warszawa 1993.

Rosenfeld A.H.: Podwójna śmierć. Rozważania o literaturze Holocaustu. Przeł. B. Krawcowicz. Warszawa 2003.

Rosenstein E.: Czas. Warszawa 1986.

Rosenstein E.: Spoza granic mowy. Warszawa 1976.

Rosenstein E.: Ślad. Warszawa 1972.

Rosenstein E.: Trochę $z$ archiwum. Legionowo 1993.

Rosenstein E.: Wszystkie ścieżki (wiersze wybrane). Kraków 1979.

SajewsKa D.: Nekroperformans. Kulturowa rekonstrukcja teatru Wielkiej Wojny. Warszawa 2016.

SENDyka R.: Śledztwo i łowy. Nie-miejsca pamięci i krajobraz cynegetyczny. W: Poetyki ekocydu. Historia, natura, konflikt. Red. A. Ubertowska, D. KorczyńsKa-PARTyKa, E. Kuliś. Warszawa 2019, s. 87-110.

SENDYKA R.: W imię zmarlych: humanistyka forensycznej wrażliwości i publicznej prawdomówności. „Teksty Drugie” 2017, nr 1, s. 81-90.

Shallcross B.: Rzeczy i Zagłada. Kraków 2010.

TAвоRska A.: Spiskowcy wyobraźni. Surrealizm. Gdańsk 2013.

UsakowsKa-Wolff U.: Odbicia na płótnie, niecichnące słowa. „Midrasz” 2014, nr 1, s. $28-31$. 


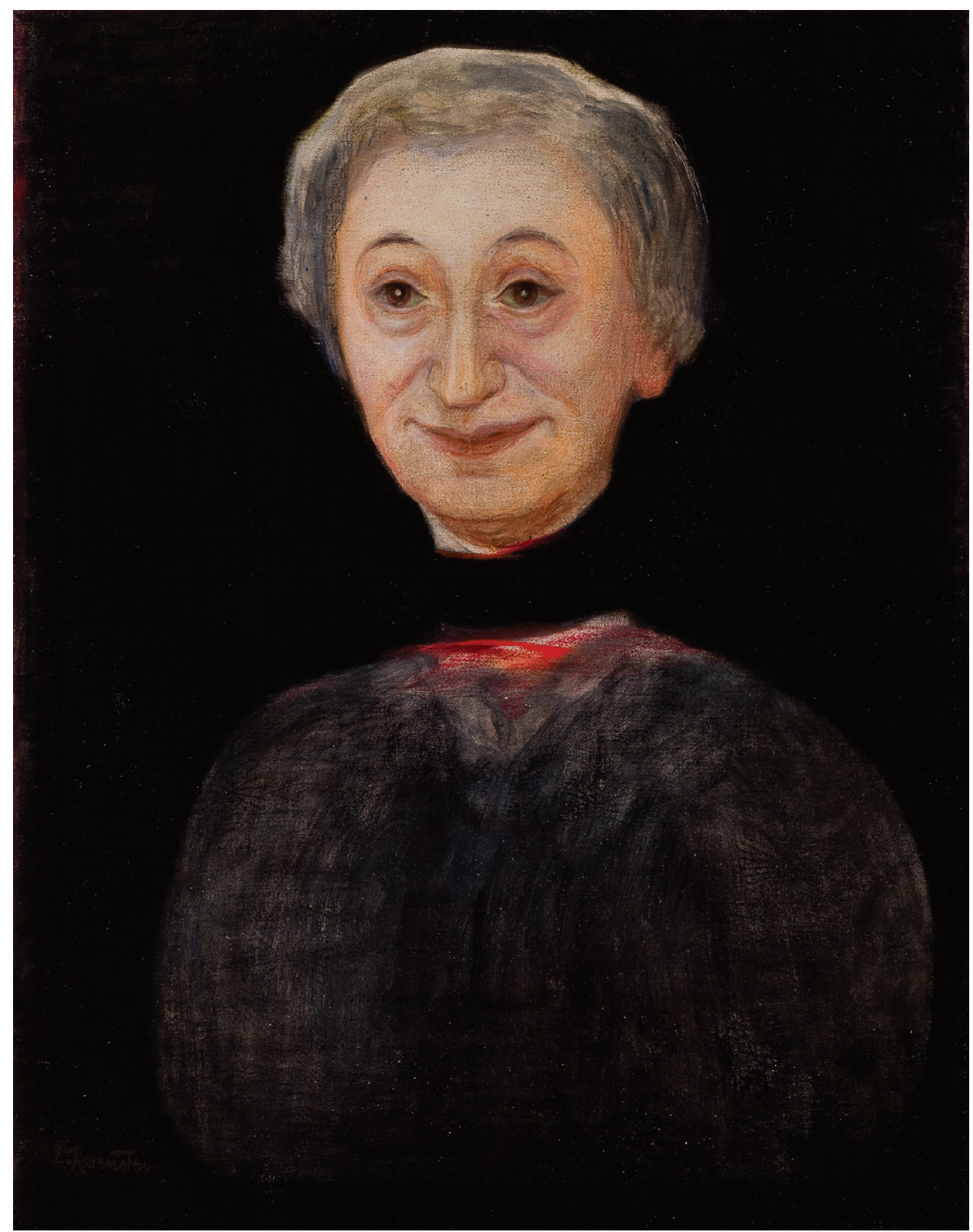

Erna Rosenstein, Pólnoc (Portret matki autorki), 1979 rok, technika mieszana, płótno, wys. 66 cm, szer. 51 cm, w zbiorach Muzeum Narodowego w Krakowie, nr inw. MNK II-b-3344. Fot. Pracownia Fotograficzna Muzeum Narodowego w Krakowie 


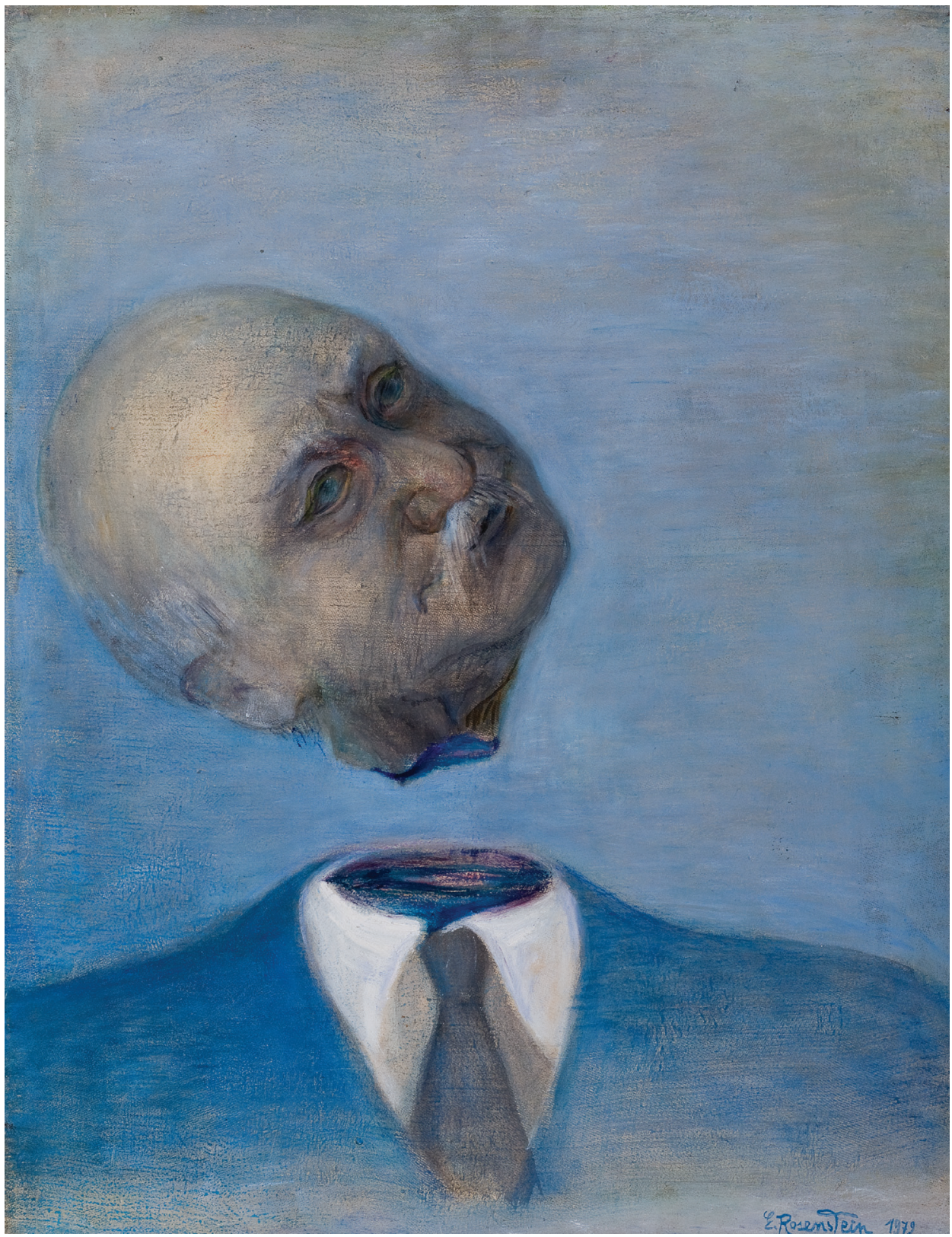

Erna Rosenstein, Świt (Portret ojca autorki), 1979 rok, olej, płótno, wys. 65,5 cm, szer. $51 \mathrm{~cm}$, w zbiorach Muzeum Narodowego w Krakowie, nr inw. MNK II-b-3345.

Fot. Pracownia Fotograficzna Muzeum Narodowego w Krakowie 
Andrzej Juchniewicz

\author{
"The Earth will open its mouth" \\ On Erna Rosenstein's Forensic Imagination
}

\begin{abstract}
Summary
Investigating Erna Rosenstein's poems containing partial accounts of her parents' murder after their escape from the Lviv ghetto, this article proposes a reading founded on two categories - forensics and shock - and therefore departs from the principles put forward by historical narratives (including the meticulous reconstruction of facts and pedantic devotedness to their organisation typical of this genre, constructing such a story whose integrity would satisfy the reader whereas moral framework would set formal limits). Forensics - a strategy that emphasises the role of material traces - is related to the clarity of a process and the rise of a community. Intuitively, Rosenstein applies a quasi-crime story narrative to her poetry, which allows it to cross the distance usually separating the victims of the Shoah from a reader belonging to an entirely different reality. The presence of a mystery makes it possible for the murdered to become close to us once again thanks to the medium of a wounded body. Shock, in turn, is a category inherent in any attempt of reaching the unthinkable (that is, the events that have not been lived through or experienced directly). Moreover, it employs affective stimulation which engages a reader in an ethical way. This article consists of three parts, whose division reflects the necessities of scrutinising Rosenstein's relation to surrealism, exploring her strategy of influencing a reader by means of affect and mood, and probing her status of a precursor, visible in the autonomy granted to the nonhuman actants or her strives for domesticating entropy.
\end{abstract}

Key words: Holocaust, Erna Rosenstein, forensic turn, affect, murder 